\title{
PĒTìJUMI
}

\author{
Evija Rutmane, Marika Lotko
}

\section{Ko iedzīvotāji un pašvaldības deputāti gaida no sociālajiem darbiniekiem?}

doi:10.25143/soc-darbs_2021_ISBN-9789934563928_073-089

Kopsavilkums. Rīgas Stradiṇa universitātē maǵistra darba izstrādes gaitā veiktā pētījuma "Iedzīvotāju un pašvaldības deputātu gaidas no sociālajiem darbiniekiem” mērķis bija izpētīt iedzīvotāju un pašvaldības deputātu gaidas no sociālajiem darbiniekiem. Balstoties uz 2016. gadā Jaunzēlandē veikto Barbaras Stenifortas (Barbara Staniforth), Lizas Bedo (Liz Beddoe) un Kelsijas Dīnas (Kelsey Deane) pētījumu, kurā sabiedrības izpratne par sociālo darbu tika salīdzināta ar to, ko sociālie darbinieki gaida no sabiedrības izpratnē par sociālo darbu un sociālajiem darbiniekiem, tika pētīts sociālo darbinieku viedoklis par to, kādas, pèc viṇu domām, ir iedzīvotāju un deputātu gaidas no sociālajiem darbiniekiem.

Pētijums notika no 2018. gada marta līdz maijam magistra darba ietvaros (autore - sociālā darba maǵistre un izglìtības zinātņu maǵistre Evija Rutmane, vadītāja - sociālā darba maǵistre Marika Lotko). Vienā pašvaldībā tika aptaujāti 97 pašvaldības iedzīvotāji, septiṇi novada sociālā dienesta sociālie darbinieki, kā arī notika padziḷinātas intervijas ar pieciem pašvaldības deputātiem.

Iegūtie rezultāti liecina, ka gan pašvaldības deputātiem, gan novada iedzīvotājiem ir neadekvātas, nerealizējamas gaidas no sociālajiem darbiniekiem, tomēr sociālo darbinieku veikums tiek vērtēts pozitīvi un atzīts par sabiedrībai nozīmīgu. Savukārt sociālo darbinieku aptaujas rezultāti liecina, ka viṇi uzskata, ka iedzīvotāji un pašvaldības deputāti sociālo darbinieku veikumu vērtē negatīvāk, nekā tas ir realitātē.

Atslēgvārdi: gaidas, sociālie darbinieki, sociālā darba vērtējums. 
E. Rutmane, M. Lotko. Ko iedzīvotāji un pašvaldības deputāti gaida no sociālajiem darbiniekiem?

\section{Ievads}

Dažādos literatūras avotos atrodams gan plašāks, gan šaurāks sociālā darba definīcijas skaidrojums. Iepazīstoties ar definīcijām, var secināt, ka sociālais darbs ir vērsts uz sociālo problēmu risināšanu, kas skar indivīdus un dažādas sabiedrības grupas, veicinot patstāvīgu cilvēka funkcionēšanu sabiedrībā, kā arī uz sabiedrības līdzdalību sociālo problēmu risināšanā mikrolīmenī, mezolīmenī un makrolīmenī. Šobrīd pasaulē sociālo darbu aplūko vēl plašāk - kā profesiju un akadēmisku disciplīnu, kas vērsta uz attīstību un pārmaiṇu veicināšanu.

Latvijas Republikas normatīvajos aktos sociālā darba definīcija tiek skaidrota Sociālo pakalpojumu un sociālās palīdzības likuma 1. pantā:

“[..] profesionāla darbība, lai palīdzētu personām, gimenēm, personu grupām un sabiedrībai kopumā veicināt vai atjaunot savu spēju sociāli funkcionēt, kā arī radīt šai funkcionēšanai labvēlīgus apstākḷus". ${ }^{14}$

Sociālajā darbā, kā ikvienā profesijā, ir noteikti profesionālie mērḳi, uzdevumi un profesionālās kompetences. Latvijā sociālā darba un sociālā darbinieka profesionālie mērḳi, profesijas saturs, profesionālās kompetences, uzdevumi u. tml. noteikti šajos normatīvajos aktos un dokumentos: Sociālo pakalpojumu un sociālās palīdzības likumā, likumā "Prasības sociālo pakalpojumu sniedzējiem", Sociālā darbinieka profesijas standartā un Latvijas sociālo darbinieku ètikas kodeksā. Sociālā darbinieka profesija Latvijā pastāv jau diezgan ilgi, tomēr, strādājot par sociālo darbinieku, nākas novērot un arī dažādos avotos lasìt, ka sabiedrības, tostarp klientu, iedzīvotāju, citu nozaru speciālistu, pašvaldības deputātu u. c., izpratne un priekšstati par sociālā darbinieka funkcijām, darba metodēm, darba jomām un profesionālajām robežām ir nepilnīga un pat maldīga.

Latvijā veiktajos pētijumos - "Sākotnējās ietekmes (ex ante) novērtējums par iecerētajām strukturālajām reformām profesionāla sociālā darba politikas jomā" (2012) un "Ex ante un ex post izvērtējumi pašvaldỉbu sociālo dienestu darbïbas efektivitātes novērtēšanai” (2016-2017) - ir secināts, ka sociālo dienestu sniegtā palīdzība iedzīvotājiem un pašvaldību vadītājiem joprojām asociējas galvenokārt ar sociālās palīdzības piešķiršanu, iedzivotāju un pašvaldību vadìtāju izpratne par sociālo darbu ir nepilnīga un sociālajiem dienestiem jāsaskaras ar iedzīvotāju gaidām, kas ir ārpus prakses robežām. ${ }^{15}$

\footnotetext{
${ }^{14}$ Sociālo pakalpojumu un sociālās palīdzības likums: Latvijas Republikas likums. Latvijas Vēstnesis. 168, 19.11.2002. https://likumi.lv/doc.php?id=68488

${ }^{15}$ Starpziņojums par sociālā darba raksturojumu Latvijā 2010./2011. gadā un tā analīzi. Latvijas Republikas Ministru kabinets. 13.07.2012. https://www.mk.gov.lv/sites/default/
} 
E. Rutmane, M. Lotko. Ko iedzīvotāji un pašvaldības deputāti gaida no sociālajiem darbiniekiem?

Arī 2017. gadā Latvijas Pašvaldību savienības veiktajā aptaujā "Sociālo dienestu kapacitāte un starpinstitucionālā sadarbība" iegūtie dati norāda uz to, ka pašvaldību politiķu izpratne par sociālo darbu bieži vien aprobežojas tikai ar sociālās palīdzības sniegšanu un sociālajiem dienestiem tiek delegêeti uzdevumi, kuri pārsniedz sociālā darba profesijas robežas. Šìs aptaujas rezultāti neatšķiras no iepriekš minētajos pētỉjumos konstatētā. ${ }^{16}$

Salīdzinot ar situāciju citās valstīs, viennozīmīgi nevar secināt, vai sabiedrības un citu iesaistìto pušu izpratne un gaidas no sociālajiem darbiniekiem Latvijā ir labākas vai sliktākas, jo pasaulē dažādos pētijumos iegūtie rezultāti ir atšķirīgi. Piemēram, ASV un Jaunzēlandē tika konstatēts, ka iedzīvotāju izpratne par sociālo darbu ir laba, attieksme pret sociālajiem darbiniekiem pozitīva, ka šis darbs tiek novērtēts. ${ }^{17}$ Savukārt Indijā un Lielbritānijā veiktajos pētijumos tika konstatēts, ka izpratne par sociālo darbu ir neliela. ${ }^{18}$ Turklāt Lielbritānijā veiktajos pētijumos norādīts, ka sabiedrības attieksme pret sociālajiem darbiniekiem, pēc pašu sociālo darbinieku domām, ir negatīva un nosodoša.

files/editor/07122012_3_2_starpzinojums_soc_darba_raksturojums.pdf; Gala ziņojums (t. sk. rekomendācijas) par profesionālā sociālā darba attīstības veicināšanu atbilstoši līgumam "Sākotnējās ietekmes (ex ante) novērtējums par iecerētajām strukturālajam reformām profesionālā sociālā darba politikas jomā". Latvijas Republikas Ministru kabinets. 10.09.2012. https://www.mk.gov.lv/sites/default/files/editor/07122012_gala_zinojums.pdf; Pašvaldību sociālo dienestu un sociālā darba speciālistu darbības efektivitātes novērtēšanas rezultāti un to analīze: Gala ziņojums. Baltic Institute of Social Sciences. Latvijas Republikas Labkläjības ministrija. 25.08.2017. http://www.lm.gov.lv/upload/ projekts/faili/5_gala_zinojums_saskanots.pdf

${ }^{16}$ Rudzīte, I. Aptaujas "Sociālo dienestu kapacitāte un starpinstitucionālā sadarbība” rezultāti. Latvijas Pašvaldību savienība. 31.03.2011. http://www.lps.lv/uploads/docs_module/1_ Aptaujas\%20\%E2\%80\%9CSoci\%C4\%81lo\%20dienestu\%20kapacit\%C4\%81te\%20un\%20 starpinstitucion\%C4\%811\%C4\%81\%20sadarb\%C4\%ABba\%E2\%80\%9Drezult\%C4\%81ti. pdf

${ }^{17}$ LeCroy, C. W., Stinson, E. L. 2004. The Public's Perception of Social Work: Is It What We Think It Is? Social Work. 49(2), 164-174; https://www.researchgate.net/publication/8580507_The_Public's_Perception_of_Social_Work_Is_It_What_We_Think_It_Is; Staniforth, B., Fouche, C., Beddoe, L. 2014. Public perception of social work and social workers in Aotearoa New Zealand. Aotearoa New Zealand Social Work. 26(2), 48-60. https://anzasw.nz/wp-content/uploads/Social-Work-Review-Volume-26-Numbers-2-and3-2014-Articles-Staniforth-Fouche-Beddoe.pdf

${ }^{18}$ Deepthi, B. Analysis on Public's Perception of Social Work. Journal of Social Work Education and Practice. 3(2), 75-78. https://www.jswep.in/uploads/3/1/7/2/31729069/030208_publics_ perception_of_social_work__.pdf; Legood, A. et al. 2016. Exploring How Social Workers Experience and Cope with Public Perception of Their Profession. The British Journal of Social Work. 46(7), 1872-1889. https://research.aston.ac.uk/en/publications/exploringhow-social-workers-experience-and-cope-with-public-perc 
E. Rutmane, M. Lotko. Ko iedzīvotāji un pašvaldības deputāti gaida no sociālajiem darbiniekiem?

Nepilnīga vai maldīga sociālā darba profesijas izpratne veicina neadekvātu, nepamatotu gaidu rašanās risku. Jēdziens "gaidas" (dažkārt lietots arī jēdziens "ekspektācijas") tiek definēts un ietekme plaši pētīta sociālajā un kognitīvajā psiholog̣ijā. Gaidas varētu skaidrot kā indivīda uzskatus, kas veidojušies, apvienojot indivīda zināšanas un pieredzi par notikumiem, kuri varētu notikt nākotnē. ${ }^{19}$

Gaidām var būt gan pozitīvas, gan negatīvas iezīmes, tās var būt gan pamatotas, gan nepamatotas. Gaidām neapstiprinoties, rodas vilšanās, dusmas, neapmierinātỉba. Gaidas ietekmē to, kā cilvēki interpretē un izprot informāciju, kāda ir cilvēku attieksme pret lietām, notikumiem un personām, tās ietekmē cilvēku rīcỉbu un lēmumus, kurus viņi pien̦em. ${ }^{20}$

Par gaidām tiek runāts ne tikai kā par indivīda gaidām attiecībā pret citiem indivīdiem, objektiem un notikumiem, bet pastāv arī indivīdu un sabiedrības "sociālās lomas gaidas" - gaidas par īpašībām un uzvedību, kas piemērota konkrētai sociālai lomai. ${ }^{21}$ Literatūrā sastopams arī jēdziens "sociālās gaidas". Koiči Hasegava (Koichi Hasegawa), Čika Sinohara (Chika Shinohara) un Džefrijs Brodbents (Jeffrey Broadbent) šo jēdzienu definē kā "internalizētu sociālo normu privātpersonām un organizācijām, tātad - sabiedrības vispārējo noskaņojumu par to, ko cilvēkiem vajadzētu darīt." 22

Viktora Vrūma (Victor Vroom) gaidu motivēšanas teorijā (expectancy theory), ${ }^{23}$ ir pausta doma, ka gaidas ietekmē katru indivīdu, arī profesionālo darbību - darba uzdevumu veikšanu, lēmumu pieņemšanu, sadarbību ar kolēgiem,

${ }^{19}$ Baumeister, R. F., Vohs, K. D. 2007. Encyclopedia of Social Psychology. Vol. 1. Great Britain: Sage Publications, 327-328; Psychology Research and Reference: Expectations. Psychology Research and Reference. https://psychology.iresearchnet.com/social-psychology/socialcognition/expectations/; McAuliff, B. D., Bornstein, B. H. 2015. Beliefs and expectancies in legal decision making: an introduction to the Special Issue. In: Beliefs and Expectancies in Legal Decision Making. Taylor \& Francis Group. New York: Routledge, 1-3.

${ }^{20}$ McAuliff, B. D., Bornstein, B. H. 2015. Beliefs and expectancies in legal decision making: an introduction to the Special Issue. In: Beliefs and Expectancies in Legal Decision Making. Taylor \& Francis Group. New York: Routledge, 1-3.

${ }^{21}$ Psychology Dictionary, s. v. "role - expectations". https://psychologydictionary.org/roleexpectations/

${ }^{22}$ Hasegawa, K., Shinohara, C., Broadent, P. B. 2007. The Effects of "Social Expectations" on the Development of Civil Society in Japan. Journal of Civil Society. 3(2), 179-180. https:// www.soc.umn.edu/assets/pdf/Hasegawa_Shinohara_Broadbent_07_JCS.pdf

${ }^{23}$ Cambridge Dictionary: expectancy theory. https://dictionary.cambridge.org/dictionary/english/expectancy-theory; Oxford Reference: alance - instrumentality - expectancy theory. Oxford University Press. http://www.oxfordreference.com/view/10.1093/ oi/authority.20110803115048339; Koontz, H., Weihrich, H., McGraw-Hill, T. 2009. Essentials of Management. An International Perspective. New Deli: Tata McGraw Hill 
E. Rutmane, M. Lotko. Ko iedzīvotāji un pašvaldības deputāti gaida no sociālajiem darbiniekiem?

taču, kā norāda Vilmārs Šaufeli (Wilmar B. Schaufeli), tās var veicināt profesionālo izdegšanu. ${ }^{24}$ Sabiedrības gaidas no konkrētas sociālās lomas ietekmē gan sociālā darbinieka profesijas novērtējumu sabiedrības skatījumā, gan profesijas prestižu kopumā.

\section{Pētījuma metodologiija}

RSU maǵistra darba izstrādes gaitā veiktajam pētījumam "Iedzīvotāju un pašvaldības deputātu gaidas no sociālajiem darbiniekiem” tika izraudzìts Rīgas reg̣iona novads, kurā 2018. gada 1. janvārī dzīvoja nedaudz vairāk kā 10000 iedzīvotāju, no tiem lielākā daḷa, gandrīz $65 \%$, bija darbaspējas vecumā. Salīdzinot ar Latvijas vidējiem rādītājiem, šajā novadā netika novērota par darbaspējas vecumu vecāku iedzīvotāju skaita palielināšanās, novadā bija augstāks vispārējais dzimstības koeficients, turpretī vispārējais mirstības koeficients bija zemāks. Bezdarba līmeņa rādītājs novadā bija zemāks nekā vidēji Latvijā un arī zemāks nekā Pierīgas statistiskajā reǵionā vidēji.

Pētỉjumā tika izmantotas trīs pētniecības metodes: novada iedzīvotāju aptauja, intervijas ar deputātiem un sociālo darbinieku aptauja.

Lai sasniegtu lielu respondentu (iedzīvotāju) skaitu, tika lietota anketēšana. Aptaujas veikšanai tika izmantota interneta vietne, un informācija par iespēju izteikt savu viedokli tika nodota, izmantojot "sniega bumbas" principu.

Anketai bija trīs daḷas:

- ievaddalı;

- demogrāfiskās informācijas daḷa;

- pamatdal̦a, kuras mērḳis bija noskaidrot iedzīvotāju zināšanas par sociālā darbinieka profesiju, iedzīvotāju gaidas no sociālajiem darbiniekiem, kā arī uzzināt sociālā darbinieka profesijas novērtējumu.

Aptaujā piedalìjās 97 iedzīvotāji.

Lai noskaidrotu pašvaldības deputātu gaidas no sociālajiem darbiniekiem, deputātu zināšanas par sociālā darbinieka profesiju, kā arī uzzinātu sociālā darbinieka profesijas un novada sociālā dienesta un tajā strādājošo sociālo darbinieku darba novērtējumu, tika veiktas padziḷinātas intervijas ar novada domes Sociālo un veselības lietu komitejas (turpmāk - komitejas) deputātiem. Intervijas sniedza visi $(\mathrm{n}=5)$ komitejas deputāti.

Education Private Limited, 292-293; Reņge, V. 1999. Organizāciju psiholog̣ija. Rīga: Kamene, 5.-16.

${ }^{24}$ Schaufeli, W. B. Burnout in Health Care. Wilmar Schaufeli. https://www.wilmarschaufeli. nl/publications/Schaufeli/256.pdf 
E. Rutmane, M. Lotko. Ko iedzīvotāji un pašvaldības deputāti gaida no sociālajiem darbiniekiem?

Anketas izstrādātājus interesējošie jautājumi bija līdzīgi Barbaras Stenifortas (Barbara Staniforth), Lizas Bedo (Liz Beddoe) un Kelsijas Dīnas (Kelsey Deane) uzdotajiem 2016. gadā Jaunzēlandē veiktajā pētījumā, kurā sabiedrības izpratne par sociālo darbu tika salīdzināta ar sociālo darbinieku gaidām par to, kāda ir sabiedrības izpratne par sociālo darbu un sociālajiem darbiniekiem. ${ }^{25}$ Tika identificēta nepieciešamība izpētìt sociālo darbinieku viedokli par to, kādas, pēc viṇu domām, ir iedzìvotāju un deputātu gaidas no sociālajiem darbiniekiem.

Lai noskaidrotu sociālo darbinieku viedokli, tika lietota anketēšanas metode. Savukārt, lai nodrošinātu sociālo darbinieku anonimitāti, anketēšana tika veikta speciālā interneta vietnē.

Anketai bija divas daḷas - ievaddal̦a un pamatdaḷa.

Anketas pamatdaḷa tika veidota tā, lai noskaidrotu sociālo darbinieku viedokli par jautājumiem, kas saistīti ar sociālo darbu, - kādas, pēc viņu domām, ir būtiskākās sociālās problēmas novadā, kuras ir svarīgākās zināšanas, kas būtu nepieciešamas sociālajiem darbiniekiem u. tml. Tāpat nolūks bija noskaidrot sociālo darbinieku viedokli par to, kādas ir iedzīvotāju gaidas no sociālajiem darbiniekiem, kādas ir iedzīvotāju zināšanas par sociālā darbinieka profesiju un kāds ir sociālā darbinieka profesijas novērtējums. Vēl mērḳis bija uzzināt sociālo darbinieku viedokli par to, kādas ir deputātu gaidas no sociālajiem darbiniekiem, deputātu zināšanas par sociālā darbinieka profesiju, kāds ir deputātu sociālā darbinieka profesijas un novada sociālā dienesta novērtējums.

Aptaujā piedalijāa nedaudz vairāk kā puse $(n=7)$ novada sociālajā dienestā strādājošo sociālo darbinieku.

\section{Respondentu raksturojums}

Aptaujā piedalijjās 97 novada iedzīvotāji, t. sk. 79,4\% sievietes, 20,6\% vīrieši. Lielākā respondentu daḷa (49,5\%) bija vecumā no 36 lìdz 50 gadiem, 25,5\% respondentu - vecumā no 51 līdz 65 gadiem, 6,2 \% - no 66 līdz 80 gadiem, 2,1 \% bija 18-25 gadus veci. Tātad anketēti tika galvenokārt iedzīvotāji darbspējas vecumā.

Respondentu lielākajai daḷai (57,7\%) bija augstākā izglìtība, 37,1\% vidējā un (vai) profesionālā izglītība, un pamatskolas izglìtỉba bija 5,2\% aptaujas dalibnieku.

${ }^{25}$ Staniforth, B., Deane, K. L., Beddoe, L. 2016. Comparing public perceptions of social work and social workers' expectations of the public view. Aotearoa New Zealand Social Work. 28(1), 13-24. https://anzswjournal.nz/anzsw/article/view/112 
E. Rutmane, M. Lotko. Ko iedzīvotāji un pašvaldības deputāti gaida no sociālajiem darbiniekiem?

Respondentu vairākums jeb 71,6 \% atzīmēja, ka strādā algotu darbu, 6,9\% norādīja, ka ir pensionāri, 4,9\% - atrodas bērna kopšanas atvaḷinājumā, 3,9\% darba meklētāji, un 2,9\% bija studenti. 9,8\% respondentu atzīmēja atbildi "cits", norādot, ka ir "mājsaimniece" $(\mathrm{n}=3)$, "strādājošs pensionārs" $(\mathrm{n}=3)$, "ir savs uzņēmums” ( $\mathrm{n}=2)$ u. c.

Anketas aizpildìtājiem tika lūgts norādìt, kāda ir respondentu līdzšinējā pieredze saskarsmē ar sociālajiem darbiniekiem. Gandrīz puse (47,7\%) iedzìvotāju personīgi pazina kādu sociālo darbinieku, 18,5 \% respondentu kāds no tuviniekiem vai radiniekiem bija vērsies sociālajā dienestā pēc palīdzìbas, un 13,8\% paši bija vērsušies sociālajā dienestā, lai saṇemtu palīdzību, daļa respondentu $(\mathrm{n}=33)$ atzīmēja vairākus atbilžu variantus. Tikai 18,5\% respondentu nebija saskarsmes ar sociālajiem darbiniekiem, un informāciju par tiem viṇi ieguvuši no plašsaziņas līdzekḷiem vai sociālajiem tīkliem, savukārt $1,5 \%$ respondentu ne tikai nav bijusi saskarsme, bet viṇi arī nebija lasījuši un dzirdējuši par sociālajiem darbiniekiem.

\section{Pētijuma rezultāti}

Pētijuma rezultātu atspoguļošanai visu respondentu grupu atbildes tika parādītas salīdzinājumā.

Lai identificētu iedzīvotāju gaidas no sociālajiem darbiniekiem, aptaujā tika iekḷauti vairāki gan daḷejji slēgtā, gan atvērtā tipa jautājumi, un viens no tiem bija: "Kādu palīdzību sagaidītu no sociālajiem darbiniekiem?” (dal̦ēji slēgtais jautājums). 17,3 \% respondentu (iedzīvotāju) atbildēja, ka sagaidītu palīdzības organizēšanu cilvēkam grūtā dzīves brīdī, 16,4\% - padomu sniegšanu, kā atrisināt dažādas problēmas, 13,7 \% - konsultācijas par to, kā saṇemt dažādus pakalpojumus, 12,4\% - vecu un slimu cilvēku aprūpi (palìdzību mājas darbos, pārtikas produktu piegādi u. tml.), 11,5\% - palīdzību cilvēkiem, organizējot dažādas atbalsta, izglìtojošas un pašpalīdzības grupas, 9,5\% - padomu un informācijas sniegšanu par jautājumiem, kas saistīti ar bērnu aprūpi, bērnu audzināšanu, $7,5 \%$ - iedzīvotāju interešu aizsardzību pašvaldībā, 6,9\% - palīdzību, piešķirot materiālos resursus (drēbes, mēbeles, sadzīves tehniku u. tml.) un tikai 4,7 \% minēja materiālā atbalsta nodrošināšanu.

Savukārt sociālajiem darbiniekiem tika uzdoti divi jautājumi: "Kā jūs uzskatāt, kāda sociālo darbinieku palīdzība būtu visvairāk nepieciešama novada iedzīvotājiem?" un "Kā jūs uzskatāt, kādu palīdzību iedzìvotāji sagaida no sociālajiem darbiniekiem?” Analizējot rezultātus, redzams, ka ir būtiskas atšķirības starp to, kā uz šo jautājumu atbildējuši iedzivvotāji, un to, ko domā sociālie darbinieki, kādas bijušas iedzīvotāju atbildes (sk. 1. tab.). 
E. Rutmane, M. Lotko. Ko iedzīvotāji un pašvaldības deputāti gaida no sociālajiem darbiniekiem?

1. tabula. Kāda sociālo darbinieku palīdzība būtu visvairāk nepieciešama novada iedzīvotājiem?

\begin{tabular}{|c|c|c|c|c|c|c|}
\hline \multirow[t]{2}{*}{ Atbilde } & \multicolumn{2}{|c|}{$\begin{array}{l}\text { Sociālo } \\
\text { darbinieku } \\
\text { viedoklis }\end{array}$} & \multicolumn{2}{|c|}{$\begin{array}{l}\text { ledzīvotāju } \\
\text { viedoklis }\end{array}$} & \multicolumn{2}{|c|}{$\begin{array}{c}\text { Sociālo } \\
\text { darbinieku } \\
\text { viedoklis par } \\
\text { to, ko sagaida } \\
\text { iedzivotāji }\end{array}$} \\
\hline & $\begin{array}{l}\text { Atbilžu } \\
\text { skaits, } n\end{array}$ & Vieta* & $\begin{array}{c}\text { Atbilžu } \\
\text { skaits, \% }\end{array}$ & Vieta* & \begin{tabular}{|c|} 
Atbilžu \\
skaits, $\mathrm{n}$
\end{tabular} & Vieta* \\
\hline $\begin{array}{l}\text { Padomu sniegšana, kā atrisināt } \\
\text { problēmas }\end{array}$ & 5 & 1. & 16,4 & 2. & 1 & $6 . / 7$. \\
\hline $\begin{array}{l}\text { Materiālā atbalsta nodrošināšana } \\
\text { (pabalsti) }\end{array}$ & 4 & $2 . / 3$. & 4,7 & 9. & 5 & 1. \\
\hline $\begin{array}{l}\text { Palīdzības organizēšana cilvēkam } \\
\text { grūtā dzīves brīdī }\end{array}$ & 4 & $2 . / 3$. & 17,3 & 1. & 1 & $6 . / 7$. \\
\hline $\begin{array}{l}\text { Padomu un informācijas snieg- } \\
\text { šana par bērnu aprūpi un } \\
\text { audzināšanu }\end{array}$ & 3 & 4. / 5. & 9,5 & 6. & 2 & 4. / 5. \\
\hline $\begin{array}{l}\text { Vecu un slimu cilvēku aprūpe } \\
\text { (palīdzība mājas darbos, pārtikas } \\
\text { produktu piegāde u. tml.) }\end{array}$ & 3 & 4. / 5. & 12,4 & 4. & 4 & 2. \\
\hline $\begin{array}{l}\text { Palīdzība, piešk̦irot materiālos } \\
\text { resursus (drēbes, mēbeles, } \\
\text { sadzīves tehniku u. tml.) }\end{array}$ & 2 & 6. & 6,9 & 8. & 3 & 3. \\
\hline $\begin{array}{l}\text { Nodrošināt konsultācijas par } \\
\text { dažādu pakalpojumu saṇemšanu }\end{array}$ & 1 & 7. & 13,7 & 3. & 2 & 4. \\
\hline $\begin{array}{l}\text { ledzīvotāju interešu aizsardzība } \\
\text { pašvaldībā }\end{array}$ & 1 & 8. & 7,5 & 7. & 0 & 8. / 9. \\
\hline $\begin{array}{l}\text { Palīdzība cilvēkiem, organizējot } \\
\text { dažādas atbalsta, interešu, izglīto- } \\
\text { jošas un pašpalīdzības grupas }\end{array}$ & 0 & 9. & 11,5 & 5. & 0 & 8. / 9. \\
\hline
\end{tabular}

* Vieta pēc atbilžu biežuma.

Iedzīvotāji $(\mathrm{n}=58)$ atbildēja arī uz atvērta tipa jautājumu, kādas ir galvenās problēmas novadā, kuras, pēc viṇu domām, vajadzētu risināt sociālajiem darbiniekiem, kas strādā novada sociālajā dienestā. Atbildes bija šādas: vecu ("ne tikai vientuḷu", "ne tikai trūcīgu pensionāru" u. tml.), slimu cilvēku aprūpe; ilgstošu bezdarbnieku atgriešana darba tirgū; darbs ar sociālā riska gimenēm (šajā gadijjumā, salīdzinot ar atbildēm uz jautājumiem, kuri atspoguḷoja iedzīvotāju viedokli par to, kādi ir sociālā darbinieka darba pienākumi, norādīts "darbs un strādāt", nevis "apsekot, uzraudzìt, kontrolēt"), kā arī darbs ("palīdzēt", "atbalstīt", "socializēt") ar šajās ğimenēs augošajiem bērniem; darbs ar atkarīgām personām; pabalstu izmaksas ierobežošana (stingrāk izvērtēt, kam pabalsts pienākas, kam ne); sabiedrības un konkrētu mērḳa grupu izglītošana; sabiedrības informēšana 
E. Rutmane, M. Lotko. Ko iedzīvotāji un pašvaldības deputāti gaida no sociālajiem darbiniekiem?

(gan par visu veidu palīdzību, ko sniedz sociālais dienests un sociālie darbinieki, gan par konkrētiem tematiem); bērnu un jauniešu nometņu organizēšana; darbs ar bērniem un jauniešiem izglìtības iestādēs (konfliktu risināšana, darbs ar atstumtajiem bērniem u. c.).

Savukārt sociālie darbinieki ( $\mathrm{n}=6)$ uzskatīja, ka iedzīvotāji galvenokārt atbildējuši šādi: būtu nepieciešama lielāka sociālā palīdzība, t. i., lielāki sociālie pabalsti (n=4); "vecu un (vai) kopjamu cilvēku aprūpe" $(\mathrm{n}=3)$; "transporta problēmas risināšana” ( $\mathrm{n}=2)$; “darbs ar sociālā riska g̣imeṇu bērniem” ( $\mathrm{n}=2)$; “jauniešu brīvā laika pavadiš̌ana", sevišķi vakaros un brīvlaikos $(\mathrm{n}=2)$; "atbalsts krīzes situācijā" $(\mathrm{n}=1)$; "alkoholisma" problēmas risināšana $(\mathrm{n}=1)$, "jaunu pakalpojumu ieviešana" $(\mathrm{n}=1)$; "palīdzība atrast darbu darbspējīgiem iedzìvotājiem" $(\mathrm{n}=1)$.

Salīdzinot sociālo darbinieku un iedzīvotāju sniegtās atbildes, var secināt, ka sociālajiem darbiniekiem prevalē uzskats par iedzīvotāju vēlmi, lai tiktu palielināta sociālā palīdzība (pabalsti), bet neviens no aptaujātajiem iedzīvotājiem nepieminēja sociālās palīdzības apjoma palielināšanu un arī "transporta jautājuma risināšanu" iedzīvotāji savās atbildes nenorādijja. Iespējams, ka tik krasa viedokḷu atšķirīiba dal̦ēji radusies tāpēc, ka vairums respondentu bija darbspējas vecumā, kā arì tāpēc, ka aptaujā nepiedalījās personas, kas regulāri saṇem sociālo palīdzību vai kam šāda palīdzība būtu nepieciešama, turpretī sociālo darbinieku viedoklis bija balstīts uz sociālā dienesta klientu uzskatiem, ne uz visas sabiedrības viedokli kopumā.

Salīdzinot citas sociālo darbinieku un iedzīvotāju atbildes, abu pušu viedokḷi galvenokārt sakrīt.

Kopumā iedzīvotāju gaidas no sociālajiem darbiniekiem raksturotas ar šādiem izteikumiem: "palīdzība (nemateriāla)", "padoms", "informācija" (šīs atbildes raksturīgas arī tiem iedzīvotājiem, kuri atzīmējuši, ka paši ir vērsušies sociālajā dienestā pēc palīdzības), savukārt sociālo darbinieku vidū prevalē uzskats, ka iedzīvotāji sagaida materiālo atbalstu gan pabalstu, gan mantiskā formā, kā arī vēlas saņemt palīdzību vecu cilvēku aprūpē. Tik izteikta viedokḷu atšķirība var veicināt sociālās politikas un sociālā darba veidošanu atbilstīgi sociālo darbinieku priekšstatiem, nevis pēc sabiedrības un iedzīvotāju vajadzībām un gaidām. Sekas būs šādas: iedzīvotāji nebūs apmierināti ar sociālo darbinieku veikumu, jo tas neatbildīs viṇu gaidām, bet sociālajiem darbiniekiem zudīs motivācija, jo iedzīvotāji nenovērtēs vai vērtēs negatīvi viṇu centienus, palielināsies profesionālo darbinieku izdegšanu veicinošais faktors.

Sociālo un veselības lietu komitejas deputāti uz jautājumu, ko viṇi sagaida no sociālajiem darbiniekiem, atbildēja, ka sagaida godprātīgu amata pildīšanu $(\mathrm{n}=2)$; sabiedrības un komitejas labāku informēšanu par to, ko sociālie darbinieki dara, par sasniegumiem un sociālā darbinieka pienākumiem, kā arī to, kas sociālajiem darbiniekiem nebūtu jādara $(\mathrm{n}=2)$; iniciatīvu $(\mathrm{n}=1)$; sadarbību ar 
E. Rutmane, M. Lotko. Ko iedzīvotāji un pašvaldības deputāti gaida no sociālajiem darbiniekiem?

pašvaldību ( $\mathrm{n}=1)$; atbildību par to, lai iesāktais darbs ar klientu tiktu arī pabeigts $(\mathrm{n}=1)$; lēmumu pieņemšanu pèc racionalitātes un juridiskiem principiem $(\mathrm{n}=1)$; klientu motivēšanu pašiem iesaistīties savu problēmu risināšanā $(\mathrm{n}=1)$, kā arī sagaida pārmaiņas $(\mathrm{n}=1)$. Izvērtējot deputātu gaidas, var secināt, ka tās ir reālistiskas, pamatotas un nepārkāpj prakses robežas.

Turpretī lielākā daḷa sociālo darbinieku, atbildot uz jautājumu, ko komitejas deputāti sagaida no novada sociālā dienesta sociālajiem darbiniekiem, uzskata, ka deputātu gaidas ir nereālistiskas un pārkāpj prakses robežas, piemēram:

"Lai atrisinātu visas situācijas un sociālos gadījumus. Lai aptver dažādas sfēras, vada pasākumus, spēj atbildēt katrā klienta situācijā, kā arī paredz uz priekšu, kā rīkosies klients."

"Lai sociālie darbinieki veiktu ne tikai sociālo darbu, bet arī risinātu dažādus citus pašvaldībā nepatîkamus jautājumus, kas būtu citu speciālistu kompetence.” "Lai vinini savas kompetences ietvaros nekavējoties risina jebkuru sociālo problēmu, par kuras risināšanas novēlošanu neapmierinātie iedzīvotāji nevērstos ar sūdzībām pie viniiem.”

Balstoties uz pētījuma autoru profesionālo pieredzi un publikācijām presē, tika modelētas trīs dažādas situācijas, kuras raksturot lūdza iedzīvotājus un komitejas deputātus, atbildot uz jautājumu, kādu rīcību katrā situācijā no sociālā darbinieka viṇi sagaidītu. Iedzīvotājiem tika piedāvāti iespējamie atbilžu varianti, bet deputātiem tas tika uzdots kā atvērta tipa jautājums.

Pirmā situācija. Vai sociālajam darbiniekam būtu jāpieškị pabalsts cilvēkam, kas vēršas sociālajā dienestā ar šādu lūgumu, bet pats ilgstoši (divus un vairāk gadus) nav strādājis algotu darbu, regulāri un pārmērīgi lieto alkoholu?

62,9\% iedzìvotāju atbildēja, ka "pabalsts nav jāpiešķir, bet jāpalīdz atrisināt problēmas, piemēram, tikt galā ar alkoholismu", 16,5\% teica, ka "nē, nebūtu, jo viņš nav to pelnijis", 10,3 \% - "nē, jo tas nav sociālā darbinieka pienākums", 8,2 \% - “jā, ja tas viṇam pienākas", 2,1 \% atzīmēja atbildi "cits", norādot, ka katra situācija jāizvērtē individuāli un ka sociālie darbinieki to nenosaka, bet to noteic normatĩvie akti.

Komitejas deputātu viedoklis dalījās - gan tika pausts viedoklis, ka sociālā palīdzība nebūtu jāpiešķir, līdz klients nav sācis strādāt algotu darbu $(\mathrm{n}=2)$, gan tika atbildēts, ka pabalsts jāpiešķir atbilstīgi normatīvo aktu prasībām, bet jāveic sociālais darbs, lai klienta sociālā situācija mainītos $(n=2)$, bet visi atbildēja, ka sagaida, lai sociālais darbinieks klientu motivētu mainīt savu situāciju.

Otrā situācija. Vai jūs sagaidāt, ka sociālais darbinieks nekavējoties sāks risināt situāciju, ja, piemēram, ğimenē, kurā aug mazs bērns (bērni), vakarā vai brīvdienās notiek pārmērīga alkohola lietošana, pieaugušo starpā rodas konflikts? 
E. Rutmane, M. Lotko. Ko iedzīvotāji un pašvaldības deputāti gaida no sociālajiem darbiniekiem?

35,7\% iedzīvotāju atzīmēja atbildi "nē, bet nekavējoties jāiejaucas citām institūcijām, piemēram, policijai un (vai) bārintitiesai”; 28,7 \% uzskatìja, ka "sociālajam darbiniekam situācija jāsāk risināt, bet sociālā darbinieka darba laikā; 14,7 \% - “jāan, nekavējoties jāierodas gimenes dzīvesvietā”; 14,7\% - "jā, jābūt sazvanāmam jebkurā diennakts laikā, arī naktīs un brīvdienās”; 2,3\% - "nē, giimenei pašai jātiek ar visu galā"; $3,9 \%$ atzīmēja atbildi "cits", norādot, ka sociālajam darbiniekam situācija jāsāk risināt nekavējoties, neatkarīgi no diennakts laika, ka sociālajam darbiniekam, ja viņš ir saņēmis šādu informāciju, jāreagee gan pēc darba laika beigām, gan brīvdienās, sazinoties ar policiju.

Visi komitejas deputāti, modelējot šĩs situācijas risinājumu, minēja, ka, lai gan tas notiek pēc darba laika vai brīvdienās, viṇi sagaidìtu, ka sociālais darbinieks iejauktos nekavējoties (ierastos ğimenes dzivesvietā), savu viedokli respondenti pamatoja ar argumentu, "lai izṇemtu bērnu no gimenes" ( $\mathrm{n}=3$ ); "lai sniegtu bērniem drošības sajūtu - ja sociālais darbinieks ar ǵimeni strādā, bērni sociālo darbinieku pazīst, un atbilstošā veidā paskaidrotu, kas un kādēl notiek" ( $\mathrm{n}=1)$; "lai nekavējoties uzsāktu intervenci" ( $(n=1)$. Trīs deputāti teica, ka šādu rīcību varētu nodrošināt, veidojot sociālo darbinieku dežūras. Divi respondenti norādīja, ka saprot situāciju un reagèt ārpus darba laika nav sociālā darbinieka pienākums, tomēr šāda rīcíba būtu nepieciešama.

Atbildes liecina, ka respondentiem ir dal̦ēja, stereotipiska izpratne par darbu ar sociālā riska ğimenēm, iespējams, tā ataino respondentu uzskatu, ka sociālais darbinieks darbā ar sociālā riska gímenēm ir nevis palīgs un atbalsta persona, bet pilda uzraudzības, kontroles un sodīšanas funkcijas. Analizējot iegūtos rezultātus, tika identificētas arī nereālistiskas gaidas - sociālais darbinieks savas funkcijas veic vienmēr, neatkarīgi no darba laika. Atšķirīgas ir iedzīvotāju gaidas, jo tikai aptuveni ceturtajai daḷai iedzīvotāju bija šādas gaidas.

Trešā situācija. Kā būtu jārīkojas sociālajam darbiniekam, ja, piemēram, vientuḷ̌s pensionārs, kurš dzīvo privātmājā, nonāktu slimnīcā, bet viṇam mājās paliktu suns, kaķis un slaucama govs, un nebūtu neviena, kurš par mājdzīvniekiem parūpètos?

Vairāk nekā puse $(59,8$ \%) iedzīvotāju atzīmējuši atbilžu variantu, ka "sociālajam darbiniekam jāsazinās ar atbilstošām institūcijām, lai organizētu mājdzīvnieku aprūpi"; 36,1 \% - "sociālajam darbiniekam būtu jāsameklē cilvēki (kaimiṇi, radinieki), kuri parūpētos par mājdzīvniekiem”, $1 \%$ - "sociālajam darbiniekam nav jārūpējas par iedzīvotāju mājdzīvniekiem, nav jāorganizē to aprūpe, par saviem mājdzīvniekiem ir atbildīgs to īpašnieks", $1 \%$ - "sociālajam darbiniekam būtu jāpabaro un jāapkopj mājdzīvnieki", 2 \% iedzīvotāju atzīmēja variantu "cits", izsakot viedokli, ka "rūpes par mājdzīvniekiem ir tikpat daudz sociālā darbinieka, kā kaimiṇu pienākums, ne vairāk”, un "ja pensionārs vai viṇa radinieki ir varējuši 
E. Rutmane, M. Lotko. Ko iedzīvotāji un pašvaldības deputāti gaida no sociālajiem darbiniekiem?

sazināties ar sociālo darbinieku, viņš (viṇi) var arī noorganizēt mājdzīvnieku aprūpi”.

Komitejas deputāti šādā situācijā sagaida, ka sociālais darbinieks apzinās sociālos resursus (kaimiņus un radiniekus), lai nodrošinātu dzīvnieku aprūpi $(\mathrm{n}=5)$; ja situāciju neizdodas atrisināt, sociālajam darbiniekam vajadzētu pašam pabarot un apkopt mājdzīvniekus $(\mathrm{n}=2)$; ja dzīves apstākḷi atḷauj, sociālais darbinieks varētu mājdzīvniekus uz laiku paṇemt uz savu dzivesvietu $(\mathrm{n}=1)$; sociālajam darbiniekam vajadzētu nogādāt mājdzīvniekus patversmē $(\mathrm{n}=1)$; sociālajam darbiniekam, kad pensionārs ir atgriezies no medicīnas iestādes, ar vinu būtu jāpārrunā, kā dzīvnieku aprūpe tiks nodrošināta turpmāk, ja atkārtosies līdzīgas situācijas, kā arī jāpalīdz izvērtēt, vai pensionāra veselības stāvoklis, ar to saistītā prombūtne, ir apvienojama ar mājdzīvnieka īpašnieka lomu $(\mathrm{n}=1)$.

No saņemtajām atbildēm redzams, ka komitejas deputātu gaidas pret sociālajiem darbiniekiem pārkāpj sociālā darba prakses robežas.

Visām respondentu grupām (iedzīvotajiem, deputātiem, sociālajiem darbiniekiem) tika jautāts, kādi, pēc viṇu domām, ir kvalitatīva sociālā darba rādītāji. Iedzīvotāji tika lūgti norādīt, kurš anketā ietvertais apgalvojums liecina par to, ka sociālie darbinieki labi strādā. Liela daḷa iedzīvotāju (22,6 \%) uzskatīja, ka labi veikts darbs būtu, ja "sociālie darbinieki aizstāvētu savas pilsētas (pagasta) iedzīvotāju intereses domē"; 19,2 \% - "sociālie darbinieki paši uzzinātu, kuriem cilvēkiem nepieciešama palīdzība, kuri ir tie cilvēki, kas nevar par sevi parūpēties, kuras gimenes nerūpējas par bērniem u. tml."; 14,0 \% - "nebūtu jāizṇem bērni no ğimenēm tāpēc, ka vecāki lieto alkoholu un nerūpējas par saviem bērniem"; 10,9\% - "sociālais dienests organizētu pasākumus pensionāriem un cilvēkiem ar invaliditāti" un "vasarā tiktu organizētas bezmaksas vasaras nometnes bērniem"; 5,7\% - "palīdzību no sociālajiem darbiniekiem varētu saņemt arī pēc plkst. 17.00 un brīvdienās" un "visi novada iedzīvotāji strādātu algotu darbu un saṇemtu algu"; 5,3 \% - "pašvaldības izmaksātie pabalsti pensionāriem, cilvēkiem ar invaliditāti būtu lielākos apmēros un daudzveidīgāki"; 3,8 \% - "uz ielām nebūtu redzami cilvēki alkohola vai narkotisko vielu reibumā"; 1,9\% atzīmējuši variantu "cits". Dominējošā respondentu atbilde bija, ka kvalitātes rādītājs ir "cilvēku labie vārdi" un tas, ka, vēršoties sociālajā dienestā, cilvēks saņem palīdzību, atrisina savas problēmas.

Sociālajiem darbiniekiem $(\mathrm{n}=6)$ tika jautāts, kuri no anketā norādītajiem kritērijiem, pēc iedzīvotāju domām, apliecina, ka sociālie darbinieki labi strādā. Lielākā daḷa $(n=5)$ atbildēja, ka kritēriji droši vien ir šādi: ja "pašvaldības izmaksāto pabalstu pensionāriem, cilvēkiem ar invaliditāti būtu vairāk un lielākos apmēros"; "nebūtu jāizņem bērni no gimenēm tādēl, ka vecāki lieto alkoholu un nerūpējas par saviem bērniem" $(\mathrm{n}=5)$; "sociālais dienests organizētu pasākumus 
E. Rutmane, M. Lotko. Ko iedzīvotāji un pašvaldības deputāti gaida no sociālajiem darbiniekiem?

pensionāriem un cilvēkiem ar invaliditāti" $(\mathrm{n}=4)$. Ja salīdzina sociālo darbinieku atbildes ar iedzīvotāju sniegtajām atbildēm (sk. 2. tab.), iedzīvotāju uzskati un sociālo darbinieku uzskati par to, kā iedzìvotāji varētu vērtēt sociālo darbinieku veikumu, ievērojami atšķiras.

Paši sociālie darbinieki un arī komitejas deputāti atbildēja, ka sociālā darba kvalitātes rādītājs ir pozitīvas pārmaiņas klienta dzīvē, klientu apmierinātība ar sañemto palìdzìbu.

Pētījuma gaitā iedzìvotājiem un komitejas deputātiem tika uzdoti jautājumi, lai identificētu respondentu attieksmi pret sociālajiem darbiniekiem un sociālā darbinieka profesiju.

2. tabula. ledzīvotāju skatījuma par sociālā darbinieka darba kvalitātes rādítājiem salīdzinājums ar sociālo darbinieku viedokli par iespējamiem iedzīvotāju priekšstatiem

\begin{tabular}{|c|c|c|c|c|}
\hline \multirow{2}{*}{ Atbilde par kvalitātes rādītāju } & \multicolumn{2}{|c|}{$\begin{array}{l}\text { Sociālo darbinieku } \\
\text { viedoklis par to, ko } \\
\text { sagaida iedzīvotāji }\end{array}$} & \multicolumn{2}{|c|}{$\begin{array}{l}\text { ledzīvotāju } \\
\text { viedoklis }\end{array}$} \\
\hline & $\begin{array}{l}\text { Atbilžu } \\
\text { skaits, } \mathrm{n}\end{array}$ & Vieta* & \begin{tabular}{|c|} 
Atbilžu \\
skaits, $\%$
\end{tabular} & Vieta* \\
\hline $\begin{array}{l}\text { Vairāk un lielāki pašvaldības izmaksātie pabalsti } \\
\text { pensionāriem un cilvēkiem ar invaliditāti }\end{array}$ & 5 & $1 . / 2$. & 5,3 & 8. \\
\hline $\begin{array}{l}\text { Palīdzība no sociālajiem darbiniekiem arī pēc } \\
\text { plkst. } 17.00 \text { un brīvdienās }\end{array}$ & 1 & 7. / 8. / 9 . & 5,7 & $6 . / 7$. \\
\hline $\begin{array}{l}\text { Visi novada iedzīvotāji strādā algotu darbu un } \\
\text { saṇem algu }\end{array}$ & 1 & 7. / 8. / 9 . & 5,7 & $6 . / 7$. \\
\hline $\begin{array}{l}\text { Uz ielām nav redzami cilvēki alkohola vai narko- } \\
\text { tisko vielu reibumā }\end{array}$ & 3 & 4. & 3,8 & 9. \\
\hline $\begin{array}{l}\text { Nav jāizṇem bērni no ǵimenēm tādēlj, ka vecāki } \\
\text { lieto alkoholu un nerūpējas par saviem bērniem }\end{array}$ & 5 & $1 . / 2$. & 14 & 3. \\
\hline $\begin{array}{l}\text { Sociālais dienests organizē pasākumus pensio- } \\
\text { nāriem un cilvēkiem ar invaliditāti }\end{array}$ & 4 & 3. & 10,9 & 4./ 5 . \\
\hline $\begin{array}{l}\text { Vasarā organizēt bezmaksas vasaras nometnes } \\
\text { bērniem }\end{array}$ & 1 & 7./8./9. & 10,9 & 4. / 5 . \\
\hline $\begin{array}{l}\text { Sociālajiem darbiniekiem pašiem jāuzzina, } \\
\text { kuriem cilvēkiem nepieciešama palīdzība, kuri } \\
\text { ir tie cilvēki, kas nevar par sevi parūpēties, kuras } \\
\text { ǵimenes nerūpējas par bērniem u. tml. }\end{array}$ & 2 & $5 . / 6$. & 19,2 & 2. \\
\hline $\begin{array}{l}\text { Sociālajiem darbiniekiem jāaizstāv savas pilsētas } \\
\text { (pagasta) iedzīvotāju intereses domē }\end{array}$ & 2 & 5. $/ 6$. & 22,6 & 1. \\
\hline Cita atbilde & - & - & 1,9 & 10. \\
\hline
\end{tabular}

* Vieta pēc atbilžu biežuma. 
E. Rutmane, M. Lotko. Ko iedzīvotāji un pašvaldības deputāti gaida no sociālajiem darbiniekiem?

Pētījumā iegūtie rezultāti liecina, ka abas grupas atzinīgi novērtē sociālo darbinieku lomu sabiedrības labklājības nodrošināšanā un sociālā darbinieka profesija tiek uztverta pozitīvi. Turklāt sociālie darbinieki uzskata, ka iedzīvotāju un deputātu sociālo darbinieku veikuma novērtējums ir negatīvāks, nekā tas konstatēts pētījuma ietvaros. Piemēram, uz jautājumu, kā sociālie darbinieki uzskata, vai iedzīvotāji piekrīt apgalvojumam, ka novadā ir nepieciešami sociālie darbinieki, lielākā daļa $(\mathrm{n}=5)$ atbildēja, ka iedzīvotāji šim apgalvojumam piekrīt vai iedzīvotāji atbildējuši, ka "varētu būt un varētu nebūt" ( $n=2)$. Savukārt lielākā daļa iedzìvotāju (76,3\%) uz šo jautājumu atbildēja "pilnībā piekrìtu", 19,6 \% - "piekrītu", 4,1\% - "varētu būt un varētu nebūt".

Pètījuma laikā tika konstatētas arī visai pretrunīgas situācijas, piemēram, sociālie darbinieki uzskata, ka novada domes deputātiem nav priekšstata vai tas ir dal̦ējs par to, kāda ir sociālo darbinieku darba specifika. Šādi savu izpratnes līmeni vērtēja arī deputāti, bet pētỉjuma laikā tika arī konstatēts, ka nekādu skaidrojošo vai izglìtojošo darbu sociālie darbinieki (sociālais dienests) neveic. Tajā pašā laikā sociālie darbinieki no deputātiem un pašvaldības gaida, ka viṇu darbs tiks izprasts un novērtēts.

\section{Secinājumi}

Pētỉjumā iegūtie dati parāda, ka gan iedzīvotājiem, gan deputātiem pastāv neadekvātas, nerealizējamas gaidas no sociālajiem darbiniekiem (viṇi uzskata, ka sociālajiem darbiniekiem savi amata pienākumi jāpilda arī pēc darba laika beigām, viņiem jāspēj identificēt un apzināt personas - konkrētus indivīdus vai gimenes -, kam nepieciešama palīdzība u. tml.). Nerealizējamās, nepamatotās gaidas, kas identificētas gan iedzīvotājiem, gan komitejas deputātiem, gan pašiem sociālajiem darbiniekiem, rada risku, ka novada sociālo politiku var veidot neatbilstoši novada iedzìvotāju sociālajām vajadzībām, ka notiek sociālā darba profesijas devalvācija un pazeminās tās prestižs, zūd sociālo darbinieku motivācija un palielinās izdegšanas risks.

Iegūtie dati arī rāda, ka sabiedrības un deputātu nepilnīgos, neatbilstošos un stereotipiskos uzskatus, kas veido neadekvātas un nerealizējamas gaidas, rada ne tikai plašsaziṇas līdzekḷi, bet arī sociālā darba prakse, sociālā dienesta popularizētās funkcijas (sociālās palīdzības un sociālo pakalpojumu sniegšana), informācijas trūkums par sociālā darba daudzveidību un sociālo pakalpojumu, kas orientēti uz dažādām iedzīvotāju mērķa grupām, daudzveidību (tas norādīts arī pētījuma "Ex ante un ex post izvērtējumi pašvaldību sociālo dienestu darbības efektivitātes novērtēšanai” secinājumos).

Šeit aprakstītajā pētījumā iegūtos datus nevar vispārināt un attiecināt uz visu Latviju, taču būtu nepieciešams veikt padziḷinātu pētijumu par to, kā sociālā 
E. Rutmane, M. Lotko. Ko iedzīvotāji un pašvaldības deputāti gaida no sociālajiem darbiniekiem?

darba prestižu, identitāti un devalvāciju ietekmē sociālo dienestu un sociālo darbinieku prakse un faktiski veiktās funkcijas, komunikācija ar sabiedrību (vai komunikācijas trūkums), sociālo darbinieku subjektīvie priekšstati par to, ko no viṇiem gaida un kā sociālos darbiniekus vērtē sabiedrība, darba devēji un sadarbỉbas partneri.

Šis pētījums parāda arī to, ka daļa iedzīvotāju sagaida no sociālajiem darbiniekiem kopienas sociālā darba realizāciju (iedzīvotāju interešu pārstāvniecību pašvaldībā, izglītojošu un atbalsta grupu organizēšanu, vasaras nometnuu organizēšanu, sociālo problēmu identificēšanu u. tml.), savukārt sociālo darbinieku norādītie dominējošie amata pienākumi (sociālās palīdzības un sociālo pakalpojumu pieškiiršana, darbs ar augsta riska ğimenēm) norāda uz to, ka sociālajam darbam jābūt mainīgam, darbiniekiem jāspēj identificēt sabiedrības vajadzības un sociālās problēmas, nepārkāpjot prakses robežas, kā arī jāvar pielāgot un attīstīt sociālo darbu (pilnveidot un attīstīt jaunas zināšanas un prasmes, mainīt un pielāgot amata pienākumus, mainìt un pielāgot darba formas u. c.).

\section{Expectations of Inhabitants and Officials of Local Municipality for Social Workers}

\section{Abstract}

The aim of the survey "Expectations of inhabitants and officials of local municipality for social workers" carried out within the framework of a Master's Thesis, which was written at Riga Stradiņš University, was to research what expectations inhabitants and officials of local municipality have for social workers. Based on the research carried out in New Zealand, in 2016, by Barbara Staniforth, Liz Beddoe, and Kelsey Deane wherein the expectations of the society for social work were compared with the expectations of social workers in terms of understanding that the society has of social work and social workers. The opinion of social workers, regarding what they believe are the expectations of inhabitants and local politicians, for social workers was researched.

The survey was carried out in 2018, between March and May, within the framework of a Master's Thesis (the author - Evija Rutmane, Mg. of Social Work and Mg. of Educational Sciences; supervisor - Marika Lotko, Mg. of Social Work). Within one municipality, 97 inhabitants and seven social workers of the municipal social services were surveyed; also, in-depth interviews were held with five local deputies. 
E. Rutmane, M. Lotko. Ko iedzīvotāji un pašvaldības deputāti gaida no sociālajiem darbiniekiem?

The results demonstrate that both local deputies and inhabitants of the municipality have inadequate and unrealistic expectations for social workers; however, the work of social workers is valued positively and seen as important for the society. The results of the survey of social workers, on the other hand, show that they believe that inhabitants and deputies evaluate the work of social workers more negatively than they do in reality.

Keywords: expectations, social workers, evaluation of social work.

\section{Avoti un literatūra}

1. Baumeister, R. F., Vohs, K. D. 2007. Encyclopedia of Social Psychology. Vol. 1. Great Britain: Sage Publications.

2. Cambridge Dictionary: expectancy theory. Iegūts no: https://dictionary.cambridge.org/ dictionary/english/expectancy-theory

3. Deepthi, B. 2018. An Analysis on Public's Perception of Social Work. Journal of Social Work Education and Practice. 3(2), 75-78. Iegūts no: https://www.jswep.in/ uploads/3/1/7/2/31729069/030208_publics_perception_of_social_work__.pdf

4. Gala ziṇojums (t. sk. rekomendācijas) par profesionālā sociālā darba attīstības veicināšanu atbilstoši līgumam "Sākotnējās ietekmes (ex ante) novērtējums par iecerētajām strukturālajam reformām profesionālā sociālā darba politikas jomā”. Latvijas Republikas Ministru kabinets. 10.09.2012. Iegūts no: https://www.mk.gov.lv/sites/default/files/ editor/07122012_gala_zinojums.pdf

5. Hasegawa, K., Shinohara, C., Broadent, P. B. 2007. The Effects of "Social Expectations" on the Development of Civil Society in Japan. Journal of Civil Society. 3(2), 179-180. Iegūts no: https://www.soc.umn.edu/assets/pdf/Hasegawa_Shinohara_Broadbent_07_JCS.pdf

6. Koontz, H., Weihrich, H., McGraw-Hill, T. 2009. Essentials of Management. An International Perspective. New Deli: Tata McGraw Hill Education Private Limited.

7. LeCroy, C. W., Stinson, E. L. 2004. The Public's Perception of Social Work: Is It What We Think It Is? Social Work. 49(2), 164-174. Iegūts no: https://www.researchgate.net/publication/8580507_The_Public's_Perception_of_Social_Work_Is_It_What_We_Think_It_Is

8. Legood, A. et al. 2016. Exploring How Social Workers Experience and Cope with Public Perception of Their Profession. The British Journal of Social Work. 46(7), 1872-1889. Iegūts no: https://research.aston.ac.uk/en/publications/exploring-how-social-workersexperience-and-cope-with-public-perc

9. McAuliff, B. D., Bornstein, B. H. 2015. Beliefs and expectancies in legal decision making: an introduction to the Special Issue. In: Beliefs and Expectancies in Legal Decision Making. Taylor \& Francis Group. New York: Routledge.

10. Oxford Reference: alance - instrumentality - expectancy theory. Oxford University Press. Iegūts no: http://www.oxfordreference.com/view/10.1093/oi/authority.20110803115048339

11. Pašvaldību sociālo dienestu un sociālā darba speciālistu darbības efektivitātes novērtēšanas rezultāti un to analīze: Gala ziņojums. Latvijas Republikas Labklājības ministrija. 25.08.2017. Iegūts no: http://www.lm.gov.lv/upload/projekts/faili/5_gala_zinojums_ saskanots.pdf 
E. Rutmane, M. Lotko. Ko iedzīvotāji un pašvaldības deputāti gaida no sociālajiem darbiniekiem?

12. Psychology Dictionary, s. v. "role - expectations". Iegūts no: https://psychologydictionary. org/role-expectations/

13. Psychology Research and Reference: Expectations. Psychology Research and Reference. Iegūts no: https://psychology.iresearchnet.com/social-psychology/social-cognition/expectations/

14. Rengèe, V. 1999. Organizāciju psiholoğija. Rīga: Kamene.

15. Rudzìte, I. Aptaujas "Sociālo dienestu kapacitāte un starpinstitucionālā sadarbība" rezultāti. Latvijas Pašvaldību savienība. 31.03.2011. Iegūts no: http://www.lps.lv/ uploads/docs_module/1_Aptaujas\%20\%E2\%80\%9CSoci\%C4\%81lo\%20dienestu\%20 kapacit\%C4\%81te\%20un\%20starpinstitucion\%C4\%811\%C4\%81\%20sadarb\%C4\%ABba \%E2\%80\%9Drezult\%C4\%81ti.pdf

16. Schaufeli, W. B. Burnout in Health Care. Wilmar Schaufeli. Iegūts no: https://www.wilmarschaufeli.nl/publications/Schaufeli/256.pdf

17. Sociālo pakalpojumu un sociālās palīdzības likums: Latvijas Republikas likums. Latvijas Vēstnesis. 168, 19.11.2002. Iegūts no: https://likumi.lv/doc.php?id=68488

18. Staniforth, B., Deane, K. L., Beddoe, L. 2016. Comparing public perceptions of social work and social workers' expectations of the public view. Aotearoa New Zealand Social Work. 28(1), 13-24. Iegūts no: https://anzswjournal.nz/anzsw/article/view/112

19. Staniforth, B., Fouche, C., Beddoe, L. 2014. Public perception of social work and social workers in Aotearoa New Zealand. Aotearoa New Zealand Social Work. 26(2), 48-60. Iegūts no: https://anzasw.nz/wp-content/uploads/Social-Work-Review-Volume-26Numbers-2-and-3-2014-Articles-Staniforth-Fouche-Beddoe.pdf

20. Starpziṇojums par sociālā darba raksturojumu Latvijā 2010./2011. gadā un tā analīzi. Latvijas Republikas Ministru kabinets. 13.07.2012. Iegūts no: https://www.mk.gov.lv/ sites/default/files/editor/07122012_3_2_starpzinojums_soc_darba_raksturojums.pdf 